(1)

\title{
SKÚMANIE PRODUKTIVITY PRI INKASE POHLADÁVOK S VYUŽITÍM INFORMAČNÝCH A KOMUNIKAČNÝCH TECHNOLÓGIÍ
}

\section{Nikoleta Puchá*}

Obchodné spoločnosti v súčasnosti stoje na viacerých základných pilieroch. Spomína sa kvalita produktov, bezpečnost' práce, nákladová efektívnost', ekológia a produktivita. .Zvyšovaním produktivity nie je možné narušit' vyššie spomínané piliere. Produktívny systém musí splńat' podmienku 3 E hospodárnost', efektívnost' (najnižšie náklady) účelnost' (ovplyvňuje výstupy, vyrábajú sa veci ktoré chce zákazník). Je možné, že sa vyrába efektívne ale nesprávne produkty. $\mathrm{Na}$ začiatku je preto potrebné, aby bol preskúmaný zákon trhu s dôrazom na zákazníkove potreby. Vo výrobe sa pod zvýšením produktivity mysli vyrobit' viac produktov, alebo znížit' nákladovost' produktu za daný čas. Uvedené súvisí s vedením spoločnosti, ktoré zodpovedá za to, že podnik je nastavený na „štíhlost““ Pod štíhlost'ou mám na mysli odstránenie plytvania napr. z nadvýroby, zbytočnú manipuláciu, čakanie na materiál, prestoje strojov a zariadení, hl'adania nástrojov, zložitú prepravu materiálu resp. sledovanie práce stroja obslužným pracovníkom a i. Vedenie by malo dbat' na neustále vzdelávanie svojich pracovníkov. Následne je potrebné nastavit' systém tak, aby bolo čo najmenej rozpracovaných pracovísk ktorými má prejst' produkt resp. služba s dôrazom na maximálnu efektivitu výrobného procesu.

V praxi neexistujú jednoznačné odporúčania na meranie produktivity. Tá sa dá merat' pomocou kvantifikovaných ukazovatel'ov, kde hodnota produktivity je vyčíslená ako súvislost' medzi nákladmi a výnosmi resp. medzi príjmami a výdavkami. Nevieme však pomerat' nekvantifikované ukazovatele napr. stupeň motivácie, vytvorený synergický efekt v súvislosti s tímovou prácou, ergonómiu vo vzt'ahu k sledovanému celku, jednotlivé vlastnosti jednotlivca a i. Tieto vo vel'kej miere priamo ovplyvňujú produktivitu a vstupujú do kvantifikovatel'ných ukazovatel'ov.

V úvode by spoločnosti mali na základe subjektívne stanovených ukazovatel'ov pomerat' súčasný stav vstupov a výstupov. Ak uvažujeme, že nastane zvýšenie produktivity tak vychádzame zo zadefinovaných kritérií:

1. Zvýšenie výstupov pri zachovanej úrovni vstupov .

2. Zníženie vstupov pri zachovanej úrovni výstupov.

3. Zvýšenie výstupov je väčšie ako zvýšenie vstupov.

4. Zvýšenie výstupov pri súčasnom znížení výstupov.

V článku následne predstavujem ohodnotenie odberatel'a v dodávatel'sko odberatel'skom vzt'ahu. Správnym ohodnotením odberatel'a vzniká predpoklad, že spoločnosti získajú finančné prostriedky za poskytnuté produkty resp. služby. Súvislost's produktivitou

\footnotetext{
${ }^{*}$ Ing. Nikoleta Puchá, PhD., Technická univerzita v Košiciach, Strojnícka fakulta, Katedra manažmentu a ekonomiky, nikoleta.pucha@tuke.sk
} 
vidím v lepšom zabezpečení výstupov ktoré sa môžu merat' napr. tržbami, príjmami resp. pridanou hodnotou a i..

\section{Dodávatel'sko - odberatel'ský vzt’ah v národnom meradle}

Dodávatel'sko-odberatel'ský vzt’ah je všeobecne postavený na uzatvorenej kúpnej zmluve. Obchodný zákonník aj Občiansky zákonník umožňujú jej ústnu i písomnú formu. Napr. po podpísaní kúpnej zmluvy, alebo dohode o dodávke tovaru, dodávatel' vystavuje faktúru.

\section{Tuzemská kúpna zmluva}

Kúpnu zmluvu upravuje Obchodný zákonník č. 513/1991 Z.z. v znení neskorších noviel. Je najčastejším zmluvným typom, na základe ktorého dochádza k uzatváraniu obchodov medzi podnikatel'skými subjektami. Podstatnými náležitost’ami kúpnej zmluvy je vymedzenie zmluvných strán (predávajúci, kupujúci) a to presne a úplne ich obchodným menom, podl'a zápisu v živnostenskom, prípadne obchodnom registri.

V zmluve je uvedené aj identifikačné číslo - IČO a sídla predávajúceho a kupujúceho. Ďalšou čast’ou zmluvy je vymedzenie predmetu zmluvy. Nie menej dôležitou náležitost'ou je záväzok predávajúceho dodat' kupujúcemu predmet zmluvy a previest' naň vlastnícke právo. Tiež záväzok kupujúceho zaplatit' kúpnu cenu. Určenie ceny patrí k podstatným častiam kúpnej zmluvy, ak strany nevyjadria v zmluve vôl'u uzavriet' ju aj bez určenia kúpnej ceny, v súlade so zákonom. Okrem podstatných náležitostí možno v kúpnej zmluve dojednat' aj d'alšie vedl'ajšie ustanovenia, napr. platobné podmienky, spôsob dodania predmetu zmluvy, lehotu na dodanie tovaru, služby a pod. [1,2,3]

\section{Faktúra}

Faktúra ako účtovný doklad na základe Zákona o účtovníctve č.431/2002 Z.z., v znení neskorších predpisov, musí spíňat' náležitosti účtovného dokladu. K ním patrí označenie účtovného dokladu, obsah účtovného prípadu, označenie účastníkov, peňažná suma alebo údaj o cene za mernú jednotku. Tiež vyjadrenie množstva, dátum vyhotovenia účtovného dokladu, dátum uskutočnenia účtovného prípadu, ak nie je zhodný s dátumom vyhotovenia. Ďalej podpisový záznam osoby zodpovednej za účtovný prípad v účtovnej jednotke. Tiež podpisový záznam osoby zodpovednej za označenie účtov, na ktorých sa účtovný príkaz zaúčtuje v účtovných jednotkách účtujúcich $\mathrm{v}$ sústave podvojného účtovníctva, ak to nevyplýva z programového vybavenia. Zákon o účtovníctve vymedzuje písomnú a technickú formu účtovného záznamu. Tým, že na základe spomínaného zákona sú obidve formy účtovných záznamov považované za rovnocenné, má obsah všetkých účtovných záznamov rovnaké dôsledky. Účtovný záznam, v technickej forme spĺn̆ajúci všetky náležitosti na základe zákona o účtovníctve, možno považovat' za účtovný doklad. Aj účtovný záznam, určený účtovnou jednotkou na prenos podl'a zákona o účtovníctve prostredníctvom informačného systému mimo účtovnej jednotky, musí obsahovat' podpisový záznam. Podpis zodpovednej osoby na účtovnom doklade bol nahradený podpisovým záznamom, ktorým sa rozumie okrem vlastnoručného podpisu, aj vlastnoručný podpis v technickej forme, napríklad elektronický podpis ${ }^{1}$, resp. zaručený elektronický podpis [4]

\footnotetext{
${ }^{1}$ Zákon o elektronickom podpise č.215/2002 Z.z. a o zmene a doplnení niektorých zákonov.
} 


\section{Využitie kaizenu pri odhade rizika odberatel'a v dodávatel'sko - odberatel'skom vzt'ahu v súvislosti s platobnou neschopnost'ou odberatel'a}

Koncepcia Kaizenu ${ }^{2}$ bola rozpracovaná v Japonsku. Ide o nepretržitý proces malých pokrokov. KAI predstavuje zmenu a ZEN zlepšenie resp. zdokonalenie. V článku zlepšenie resp. zdokonalenie je $\mathrm{v}$ tom, že dodávatel' pomocou údajov v tabul'ke dokáže lepšie ohodnotit' svojho klienta. Navrhnuté zdokonalenie by malo pomôct' dodávatel'ovi pri hodnotení svojho odberatel'a v súvislosti s tým či bude vyžadovat' platbu v hotovosti, alebo mu poskytne predíženú lehotu splatnosti so zabezpečením, alebo bez zabezpečenia. Faktory ktoré navrhujem posudzovat' v súvislosti s metódou multikriteriálneho rozhodovania prestavuje tabul'ka č.1. Váhy sú stanovené subjektívne. Viackriteriálne rozhodovanie, patrí pod odvetvie optimalizácie. Pre vysvetlenie princípu multikriteriálneho rozhodovania uvádzam v skrátenej forme niektoré dôležité pojmy a predpoklady:

$$
\min _{x \in M} \mathbf{f}(x),
$$

pričom $M$ je l'ubovol'ná množina, $R$ je množina reálnych čísel, f: $M \rightarrow R^{\mathrm{m}}$ je vektorová funkcia, takže f $(x)$ je vektor o zložkách $\left(f_{1}(x), \ldots, f_{m}(x)\right)$.Zvyčajne sa zavádza pojem tzv. eficientného riešenia. Bod $x \varepsilon M$ je eficientné riešenie danej úlohy, ak pre všetky $y$ $\varepsilon M$ platí následujúca implikácia: ak je $f_{i}(x)>f_{i}(y)$ pre nejaké $i \varepsilon\{1, \ldots, m\}$, potom existuje $j$ $\varepsilon\{1, \ldots, m\}$ tiež, že $f_{j}(x)<f_{j}(y)$. Nedominované riešenie tak nejde $\mathrm{v}$ jednom kritériu zlepšit bez toho, aby sa v inom kritériu zhoršilo.

Eficientné riešenie sa často hl’adá v tvare

$$
\min _{x \in M} \sum_{i=1}^{m} \lambda_{i} f_{i}(x), \quad \lambda_{i} \geq 1
$$

kde $\lambda_{\mathrm{i}}$ sú subjektívne nadefinované váhy [5].

\footnotetext{
${ }^{2}$ Vid' bližšie koncepciu Kaizen [6]
} 
Bodové hodnotenie by vychádzalo z nasledovného určenia 1 - žiadne riziko, 2 - minimálne riziko, 3 - akceptovatel'né riziko, 4 - neprijatel'né riziko.

\begin{tabular}{|l|c|c|}
\hline Faktory & Váha & $\begin{array}{c}\text { Bodové ohodnotenie } \\
\text { min.hod. (žiadne riziko) - } \\
\text { max.hod. (neprijatel'né } \\
\text { riziko) }\end{array}$ \\
\hline 1. Právna forma a manažment & 0,07 & $1-4$ \\
\hline 2. Dížka pôsobenia na trhu & 0,03 & $1-4$ \\
\hline 3. Situácia v odvetví odberatel'a & 0,05 & $1-4$ \\
\hline $\begin{array}{l}\text { 4.Značkaodberatel'a/Kvalita výrobku/Využívanie } \\
\text { moderných technológií }\end{array}$ & 0,15 & $1-4$ \\
\hline 5. Bonita odberatel'a, Likvidita & 0,25 & $1-4$ \\
\hline 6.Využívanie IaK technológií (reklama, referencie) & 0,13 & $1-4$ \\
\hline $\begin{array}{l}\text { 7. Cena produktu odberatel'a v porovnaní s cenou } \\
\text { na trhu }\end{array}$ & 0,02 & $1-4$ \\
\hline $\begin{array}{l}\text { 8. Výška objemu obchodu, Periodicita odberov } \\
\text { v súvislosti s dlhodobou spoluprácou }\end{array}$ & 0,10 & $1-4$ \\
\hline $\begin{array}{l}\text { 9. Nedoplatky voči Sociálnej poist'ovni, zdravotnej } \\
\text { poist'ovni a daňovému úradu }\end{array}$ & 0,20 & $1-4$ \\
\hline Spolu & 1,00 & $1-4$ \\
\hline
\end{tabular}

V prípade, že dodávatel' v súčte ohodnotil odberatel'a s pomocou stanovených faktorov medzi jednotkou a dvojkou, predpokladám, že na základe subjektívne navolených váh (každý dodávatel' si ich môže prispôsobit' trhovým podmienkam) vykazuje odberatel' nízke riziko v súvislosti s nevyplatením záväzku. Dodávatel' môže poskytnút' odberatel'ovi predíženú lehotu splatnosti, pretože riziko nezaplatenia zo strany odberatel'a je malé.

V prípade, že dodávatel'ovi vyjde hodnota väčšia ako dva, ale menšia, alebo rovná 3, tak odberatel' pre dodávatel'a predstavuje zvýšené riziko. Mohol by požadovat' zabezpečenie pohl'adávky tret’ou stranou napr. avalom zmenky, poistením pohl'adávky, bankovou zárukou, dokumentárnym akreditívom a i.

V prípade výsledku medzi 3 a 4 ide o značné riziko a dodávatel' by mal požadovat' platbu v hotovosti.

\section{Popísanie faktorov}

\section{Právna forma a manažment}

Pri kapitálových spoločnostiach je možné zistit' výšku základného imania na webovej stránke www.orsr.sk. Uvedené je potrebné skúmat' aj v súvislosti s ručením za prípadné záväzky. Výpis konkrétnej společnosti hovorí aj o štatutárnom orgáne spoločnosti o spôsobe akým štatutárny zástupca koná menom spoločnosti. V prípade živnostenského podnikania sú všetky potrebné údaje dostupné na www.zrsr.sk. Živnostník ručí celým svojim majetkom. Na sledovanie väzieb sa využíva aj sociálna siet' Obchodného registra, dostupná na www.foaf.sk.

\section{Dĺžka pôsobenia na trhu}

Dížku pôsobenia na trhu ako faktor som zaradila $\mathrm{z}$ dôvodu, že v prípade ak spoločnost' má nejakú históriu je možné získat' „obraz“ o minulosti v súvislosti so správaním spoločnosti na trhu. Dížka pôsobenia spoločností sa dá zistit' tiež aj z výpisu z Obchodného a Živnostenského registra. 


\section{Odvetvie}

Vývoj svetového hospodárstva v období globalizácie nadobúda nové dimenzie. Objem svetového obchodu vrátane tzv. vnútrofiremného, má vysoký podiel na celosvetovom hrubom domácom produkte. V súčasnosti, v období globálnej finančnej a hospodárskej krízy sa zvlášt' treba zamysliet' aj nad odvetviami, prostredníctvom ktorých sa tovary aj služby dostávajú ku konečnému spotrebitel'ovi. Určit', či vykazujú rast resp. znášajú negatívne dôsledky, ktoré priniesla kríza. Informácie sa dajú vyčítat' z elektronických stránok napr. www.etrend.sk, www.atpjournal.sk a i.

\section{Značka odberatel'a/Kvalita výrobku}

Kvalita je základ v koncepcii Kaizenu. Čím je vyššia kvalita, tým skôr je predpoklad, že značka na trhu bude úspešná. Zároveň moderné technológie umožňujú minimalizáciu nákladov a maximalizáciu zisku.

\section{Likvidita, Bonita odberatel'a}

Schopnost' splácat' záväzky si môže dodávatel' overit' pri spoločnostiach, ktoré majú legislatívnu povinnost' zverejňovat' svoje hospodárske výsledky. Informácie predstavujú základný predpoklad úspechu. Obchodné informácie nestrácajú na hodnote, ich využitie je dlhodobé. Aby nevzniklo informačné vákuum, legislatíva stanovila vybrané firemné informácie za verejné, každému dostupné. Ide o údaje registračné (identifikačné), finančné, ako i o niektoré doplnkové dáta, ktoré vytvárajú reálnejší obraz o perspektívach a fungovaní spoločnosti. Zákonná úprava je nutná i preto, aby požadované informácie boli firmami poskytované v rovnakej štruktúre, ktorá je východiskom ich porovnatel'nosti. Tento postup je v súlade s direktívami Európskej únie [8]. Majetok odberatel'a je zdokumentovaný v súvahe, alebo vo výkaze majetku a záväzkov (jednoduché účtovníctvo). Prostredníctvom centrálneho registra záložných práv sa dajú tiež zistit' súvislosti s majetkom fyzickej resp. právnickej osoby. Register je dostupný na http://www.notar.sk/cr_zp_search.aspx. Stránka katastrálneho úradu https://www.katasterportal.sk/kapor/ poskytuje údaje o vlastníkoch bytov, nebytových priestorov, pozemkov a i.

\section{Využivanie informačných a komunikačných technológií}

V prípade, že odberatel' má vlastnú stránku a využíva výhody elektronického obchodu je predpoklad, že zaujme vyšší počet zákazníkov s pomocou I a K technológií.

\section{Cena produktu odberatel'a $v$ porovnaní s cenou na trhu}

Dodávatel' by nemal zabúdat' ani na porovnanie identických resp. porovnatel'ných produktov pri vyhodnocovaní či poskytne predíženú lehotu splatnosti pohl'adávky pre svojho odberatel'a. Váha je navolená na základe toho, že už sám trh určuje maximálnu cenu.

\section{Výška objemu odberu, Periodicita odberov v súvislosti s dlhodobou spoluprácou}

Čím je hodnota pohl'adávky vyššia, tým viac predstavuje možné riziko nevyplatenia. V prípade predchádzajúcej spolupráce je možné zistit’ inkaso pohl’adávok.

\section{Nedoplatky voči Sociálnej, zdravotnej poistovni a daňovému úradu.}

Nedoplatky voči Sociálnej poist’ovni je možné overit' na webovej stránke Sociálnej poist'ovni, dostupné na http://www.socpoist.sk/77/487s. Aj zdravotné poist'ovne zverejňujú zoznamy svojich dlžníkov. Daňový úrad má prístupnú elektronickú stránku http://www.drsr.sk/, kde sa prostredníctvom poskytovania informácií a následne informačných zoznamov dá otvorit’ zoznam dlžníkov. 


\section{Záver}

V podmienkach „trhu kupujúcich“, sú predávajúci z dôvodu konkurencieschopnosti nútení poskytovat' svojim obchodným partnerom predížené lehoty splatnosti pohl'adávok. Riziko nezaplatenia pohl'adávky ostáva teda na strane predávajúceho, viaže mu peňažné prostriedky a spomal'uje obrat. V príspevku predstavené vyhodnotenie odberatel'a zo strany dodávatel'a pomôže detailnejšie odhadnút' odberatel'a (rating odberatel'a), aj v súvislosti s predstavenými webovými stránkami s využitím informačných a komunikačných technológií.. Uvedené v čase hospodárskej a finančnej krízy pomôže eliminovat' prvotnú a následne aj druhotnú platobnú neschopnost'.

\section{Literatúra}

[1]Dibdiaková, D.: Obchodný zákonník s komentárom. Poradca s.r.o, Žilina, 8/2002, ISSN: 1335-1583.

[2]Kolektív autorov.: Zmluvy právnych podaní a zmlúv s komentárom II.Žilina SEPI, 9/2006, ISBN: 80-88961-33-5.

[3]Škrinár, A. a kol.: Aktuálne vzorové zmluvy pre obchodný styk. Verlag Dashöfer, Bratislava,2003, ISBN:1335-8502.

[4]Oberhauser, J a kol.: Sprievodca postupmi účtovania. Bratislavské tlačiarne, Bratislava, 2006.

[5]Wikipédia,: Viackriteriálne rozhodovanie, na http://sk.wikipedia.org/wiki/Viackriteri\%C3\%A1lne_rozhodovanie

[6]Imai, M.: Gemba kaizen, Computer press, Brno, ISBN: 80-251-0850-3

[7]Šebejová, K.: Význam informácií pre transparentnost' podnikatel'ského prostredia, Biatec, ročník 12,1/2004. 